\title{
Paulus se hantering van eksterne stressors, en die verhouding tussen identiteit, etiek en etos in Filippense
}

\begin{abstract}
Author:
Chris Franken

Affiliation:

${ }^{1}$ Department of New

Testament, University of

Pretoria, South Africa

Note:

Dr Chris Franken is a

doctoral candidate and a

research associate

of Prof. Dr Kobus Kok

in the department

New Testament at the

University of Pretoria.

This article resulted from

the student's

doctoral thesis that he

successfully completed at

the University of Pretoria

in 2011.
\end{abstract}

Correspondence to:

Kobus Kok

Email:

kobus.kok@up.ac.za

Postal address:

University of Pretoria,

Lynwood Avenue, Pretoria

0002, South Africa

Dates:

Received: 26 July 2011

Accepted: 22 Feb. 2012

Published: 16 July 2012

How to cite this article: Franken, C., 2012, 'Paulus se hantering van eksterne stressors, en die verhouding tussen identiteit, etiek en etos in Filippense', HTS Teologiese Studies/ Theological Studies 68(1), Art. \#1148, 11 pages. http:// dx.doi.org/10.4102/hts. v68i1.1148
(C) 2012. The Authors. Licensee: AOSIS OpenJournals. This work is licensed under the Creative Commons Attribution License.
Paul coping with external stressors: Exploring the relationship between identity, ethics and ethos in Philippians. Stress is one of the most prominent sicknesses of the third millennium. This article used the external categories of stress and the heuristic ethical indicators (identity, ethics and ethos) to determine why Paul lived with joy despite of his stressful circumstances. As for people sharing the same Christian identity of the first followers of Jesus, this should be of real significance to the situation of stress in the third millennium.

\section{Fokus en metodologie}

Stephan Joubert (2009:24) het na stres verwys as 'die groot siekte van millennium drie'. Teen hierdie agtergrond sal hierdie artikel die volgende probleemstelling ondersoek: Kan Paulus se skrywe aan die Filippense die Christen in millennium drie help om stres sinvol te deurleef? Die uitgangspunt is dat Paulus ten tyde van sy skrywe aan die Filippense aan eksterne stressors onderworpe was, maar dat hy met die blydskapsmotief kon leef omdat daar by hom 'n verband tussen die etiese indikatore identiteit, etiek en etos was (vgl. Kok 2010:1-5, 2011:2-3 en Van der Watt 2006:v-ix). Wat metodologie betref, kan die stresmodel, soos die leser voor die teks dit verstaan, nie direk op Paulus se lewe toegepas word nie, want so 'n werkswyse kan tot die gevaar van etnosentrisme aanleiding gee. Die werke van Bergh en Theron (2004) aangaande die kategorieë van stres en Van der Watt (2006:v-ix) se etiese indikatore, naamlik identiteit, etiek en etos, word as heuristiese kategorieë aangewend om 'n eksegetiese en sosiaal-wetenskaplike ondersoek oor stres as 'n verskynsel in die antieke tyd en die hermeneutiese boodskap daarvan vir vandag te ontsluit. Daar sal op Paulus se brief aan die Filippense gefokus word.

\section{Omskrywing}

\section{Kategorieë van stres}

Die stresmodel word binne die konteks van hierdie artikel geïnterpreteer in terme van die kategorieë stressors, soos aangedui in Bergh en Theron (2004:399). Hulle noem drie kategorieë stres: naamlik frustrasie, konflik en druk. Frustrasie dui daarop dat iemand om die een of ander rede verhinder word om sy of haar doelwitte te bereik. Die mate van toleransie is weer afhanklik van die funksie van aangeleerde gedrag, met ander woorde, hoe het ek geleer om my behoeftes te bevredig. Die volgende kategorie waarna Bergh en Theron (2004:399) verwys, is konflik. Konflik is wanneer 'n persoon ' $n$ verskeidenheid behoeftes op dieselfde tydstip moet bevredig. Die stres word verskerp wanneer die persoon sterk negatiewe en positiewe gevoelens oor dieselfde keusemoontlikheid het. Die derde kategorie het te make met 'druk' (Bergh \& Theron 2004:399). Die verwagtinge om in verskeie lewensrolle te presteer of te konformeer, kan tot chroniese druk en uitbranding lei. Die mate waartoe iemand sy of haar lewensomstandighede as 'n stressor beleef, word bepaal deur die belang, tydsduur, hoeveelheid verwagtinge en nabyheid van gebeure, maar ook deur die persoon, wat daaglikse gebeure as relevant, irrelevant of bedreigend interpreteer, se persepsie (Bergh \& Theron 2004:399). 'n Verdere belangrike faktor in die ervaring en hantering van stres het te make met die integrering van eksterne (byvoorbeeld ondersteuning deur vriende en familie) en interne bronne (soos byvoorbeeld 'n positiewe gesindheid en interne lokus van kontrole) van streshantering.

\section{Eksterne stressors in Paulus se lewe}

Bogenoemde heuristiese kategorieë (frustrasie, konflik en druk) word in gesprek gebring met die inligting in Filippense deur dit hermeneuties met die eksegetiese resultate in Filippense te integreer. Moontlike eksterne stressors in Filippense word geïdentifiseer as: Frustrasie - Paulus se tronkstraf (1:12-14), die bedreiging van die gemeente-eenheid (3:2; 4:2), en die afstand tussen Paulus en sy geliefdes $(1: 2,3,5,7-8 ; 1: 19 ; 3: 18)$; Konflik - Paulus se worsteling oor die lewe en die dood (1:21-24; 2:17); en Druk - die dwaalleraars wat die besnydenis tot die kern van die evangelie van Christus wou toevoeg $(1: 15-17 ; 3: 2)$. 


\section{Etiese indikatore}

Van der Watt (2006:v-ix) se wetenskaplike benadering maak voorsiening vir die sogenaamde etiese indikatore soos vergestalt in identiteit, etiek en etos. Identiteit dui op die selfdefiniëring van die persoon en het 'n rigtinggewende invloed op dit wat volg, naamlik die etiek en etos. Identiteit impliseer die vraag: Wie is ek? Etiek dui op die fundamentele grondreëls vir die optrede van 'n individu of 'n groep, maar vervat ook die motivering vir optrede. Die derde indikator is etos. Etos beskrywe die gedragskomponent van identiteit en etiek. Die interafhanklikheid tussen identiteit, etiek en etos bied 'n teologiese asook 'n terapeutiese sleutel tot die verstaan van Paulus se hantering van sy stressituasie asook tot die relevante toepassing daarvan op die lewe van die moderne leser. Die raakpunt tussen die Filippense, Paulus en die moderne leser lê daarin dat sowel die leser voor die teks as die leser agter die teks oor ' $n$ gedeelde identiteit in Christus beskik. Dit is hierdie gedeelte identiteit in Christus wat as etiese indikator 'n performatiewe herstelde identiteit, etiek en etos wil laat realiseer. In die Nuwe Testamentiese denke word identiteit altyd aan dade gekoppel en dade word beskou as iets wat uit identiteit voortvloei. Van der Watt (2006:v-ix) voer aan dat die etiese indikatore wat identiteit, etiek en etos in stand hou, deur middel van die sogenaamde deskriptiewe taak ontsluit word. Toegepas op die lees van Filippense beteken dit dat bestaande etiese indikatore binne Filippense met vrug op die moderne Christen se leefwêreld toegepas kan word. Van der Watt (2006) stel dit soos volg:

By identifying what might generally be called 'ethical indicators or trajectories' the appropriateness, acceptability, or even necessity of particular types of behaviour might become apparent. This should be of real significance in formulating similar 'ethical indicators or trajectories' for people sharing the Christian identity of the first followers of Jesus. (bl. vi)

\section{Die verband tussen die etiese indikatore in Filippense}

Die heuristiese kategorieë identiteit, etiek en etos word aangewend om te bepaal wat dit vir Paulus moontlik gemaak het om te midde van eksterne stressors met blydskap as motief te leef. Bogenoemde etiese indikatore vind onder andere uitdrukking binne die inter-relasionele verband van die 'fiktiewe verwantskap' met God as primêre weldoener en Jesus Christus as middelaar tussen God en mens (vgl.

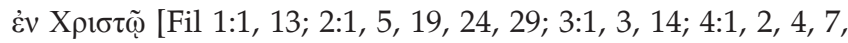

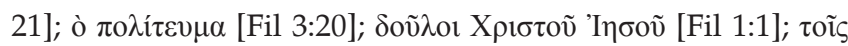

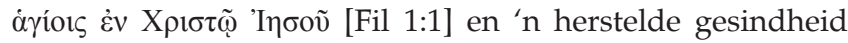
[Fil 2:5-11]).

\section{Fiktiewe verwantskap}

Paulus se herstelde identiteit, etiek en etos kan ook binne die konsep 'fiktiewe verwantskap' (fictive kinship) geplaas word. Die begrip verwantskap dui op familiebande en fiktief impliseer dat persone buite die bloedlyne en natuurlike genealogiese lyne van die familie hanteer word asof hulle volwaardig deel is van ' $\mathrm{n}$ familie (Achtemeier, Green \&
Thompson 2001:47). Brown (2003:204) asook Kok en Van Eck (2011:148) is van mening dat die familie die vernaamste groepsordening in die destydse wêreld was en dat die mees uitstaande kenmerk van die antieke Mediterreense familielojaliteit jeens mekaar was. Sowel die fiktiewe verwantskap as die tradisionele familie se eer het daarin gelê om, soos Brown dit stel, 'to stay connected'. Malina en Neyrey (1996) omskryf die fiktiewe verwantskap soos volg:

'Fictive family' in antiquity designates a group that has a structure and many of the values of the patriarchal family: a central person who is like a father, with members who treat each other as siblings. (bl. 160)

Paulus het juis hierdie lojaliteit ervaar terwyl hy in die tronk was. Waaraan kan hierdie besondere ervaring van lojaliteit tussen Paulus en die Filippense toegeskryf word?

Toegepas op die Christengemeenskap in die Nuwe Testament is dit belangrik om daarop te let dat Jesus Christus die mense van sy tyd uitgedaag het om van sy fiktiewe familiestruktuur deel te word deur hulle kruis op te neem en Hom te volg (Crook 2004:68; Neyrey \& Stewart 2008:96). Die kruis was 'n metafoor vir die negatiewe - fisiek sowel as sosiaal-maatskaplik. Die lyding in hierdie 'kruis opneem en Jesus volg' was daarin opgesluit dat persone dikwels hul eie huishouding verlaat het en hulle by die fiktiewe familie van Jesus Christus aangesluit het. Eer in die oë van Christus en sy familie het dikwels tot skande in die oë van die genealogiese familie gelei (Neyrey \& Stewart 2008:96). Binne die fiktiewe familiestruktuur van die Christus-beweging is God die paterfamilias, Jesus die makelaar of tussenganger of bemiddelaar of agent en die gemeente en medewerkers van Paulus die boers en susters van die nuwe familie, met Paulus as die veranderingsagent (Horrell 1999:353; Malina \& Pilch 2006). Myns insiens kan daar gepostuleer word dat lojaliteit, soos vergestalt in die fiktiewe familiestruktuur, as ' $\mathrm{n}$ antitese tot die stressors in Filippense geïdentifiseer kan word. Binne die antieke Mediterreense antropologie was die fiktiewe familie 'n uiters belangrike verhoudingsnetwerk en simboliese universum waarbinne Paulus gefunksioneer het. Hieruit is sy identiteit, etos en etiek gekonstrueer, en dit het gelei tot bepaalde singewing in kontekste van stres, vervolging, verwerping en teenspoed (vgl. Harrison 2003; Malina \& Neyrey 1996). Wanneer 'n mens oor die etiese of morele dimensie van streshantering in Filippense handel, kan jy dus met Meeks (1993:1-17) saamstem dat alle moraliteit groepsmoraliteit is. Daarmee bedoel Meeks (1993:1-17) dat reëls, gedrag en die hantering van konflik sosiaal gekonstrueer is en binne die simboliese universum van ' $n$ bepaalde groep tot stand kom, aanpas, muteer en transformeer. Dat die fiktiewe familiestruktuur vir Paulus 'n belangrike komponent was en met die hantering van eksterne en interne stessors saamgehang het, word duidelik uit die voorkoms van die term $\dot{\alpha} \delta \varepsilon \lambda \varphi \hat{c}_{\varsigma}$ in die brief. Paulus gebruik die term ả $\delta \varepsilon \lambda \varphi$ ò $\varsigma$ agt keer (kyk na Fil 1:14; 2:25; $3: 1,13,17 ; 4: 1,8,21)$. Die gebruik hiervan impliseer dat Paulus almal broers en susters van mekaar maak en so van die voorveronderstelling van ' $n$ fiktiewe familie uitgaan. 
Toegepas op Paulus, is Porter (2008:203) van mening dat Paulus telkens na mede-Christene verwys in die terminologie van fiktiewe familie: 'referring to people who are not related to each other by other family ties, such as birth or legal adoption'. Paulus plaas sy medewerkers ook binne die fiktiewe familie-kategorie (kyk na Fil 2:25). Dieselfde beginsel geld egter nie wanneer Paulus na nie-Christene nie verwys, omdat hulle aan die 'uit-groep' behoort. Die nie-Christen of teenstanders van die Christelike geloof word deur Paulus in sy gebruik van die fiktiewe familiestruktuur uitgesluit (Porter 2005:66). Dat Paulus slegs medegelowiges in sy verstaan van die fiktiewe familie ingesluit het, beteken nie dat hy dit as 'n uitsluitlik Christelike verskynsel beskou het nie. Porter (2005:67) maak die stelling dat Paulus byvoorbeeld na die 'fiktiewe familiestruktuur van die teenstanders van die Christelike geloof verwys het as "pseudo".

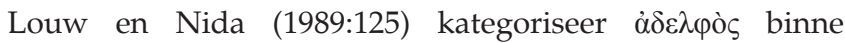
twee semantiese velde, (1) 'kinship relations of the same generation (10:49-10:52)', en (2) 'groups and classes of persons and members of such group and classes (11:1211:54)'. Binne die eerste kategorie ('kinship relations of the

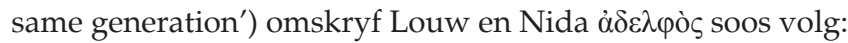
'a male having the same father and mother as the reference person - brother'. Belangrik vir die toepassing van hierdie begrip deur die lens van die moderne leser (leser voor die teks) is dat die meervoudsvorm van $\alpha \delta \varepsilon \lambda$ pòs ook kan dui op 'susters' waar dit figuurlik as 'n aanduiding van Jesus se volgelinge aangewend word (Louw \& Nida 1989:118). Die tweede semantiese veld waarbinne Louw en Nida $\alpha \delta \varepsilon \lambda \varphi \grave{s}$ plaas, word soos volg omskryf: 'a close associate of a group of persons having a well-defined membership - fellow believers, in Christ.'

Die onderlinge lojaliteit (etos) sowel as die herstelde identiteit het in die fiktiewe verwantskap uit die beginsel van 'n teologies gefundeerde basis (in Christus) ontspring. Dit vind sy hoogtepunt in die etos van 'sekulêre hesed' en 'godsdienstige hesed' (Jensen 2006:99). Die semantiese konsep lojaliteit, soos verskans in 'hesed', moet in terme van die verbondsteologie geïnterpreteer word (Bruegemann \& Miller 1995:201). Die verbondsteologie maak voorsiening vir die beginsel van wederkerigheid, wat Paulus binne die dampkring van God as 'beskermheer' opgeneem het. In hierdie opsig het Paulus bestaande sosiaal-kulturele denke oor eer, status en mag herdefinieer. Voortaan sou Paulus sy identiteit daarstel op grond van die gerekonstrueerde Godsbeeld as kognitiewe konstruk, waarbinne God as die lojale Vader die inisiatief neem om sy Seun as sy beeld te gee of stuur (vgl. Fil 2:5-10). Hy verwag dat daar etiese resiprositeit sal wees wat gewortel is in die indikatief van die fiktiewe verwantskap met voortvloeiende etos wat eie is aan die aard van die betrokke familie. Konflik en stres as dekonstruktiewe elemente en potensiële kragte wat die fiktiewe familienetwerk skade kan berokken, word teologies binne die dampkring van die alternatiewe simboliese universum van die fiktiewe verwantskap geplaas. Dit transformeer die aard en interpretasie van die dekonstruktiewe elemente wat beleef word en transformeer die betekenisvormingsproses daarvan.

\section{God en Jesus Christus as weldoener}

Die verwysing na God as weldoener en Jesus Christus as makelaar (broker) moet binne die paradigma van die antieke Mediterreense samelewing verstaan word. In Filippense is God die primêre weldoener en is Hy die een wat Jesus bemagtig en verhoog tot die posisie van bemiddelende weldoener, terwyl gelowiges vir alle praktiese doeleindes die kliënte is (vgl. Fil 2:5-10). Alhoewel daar natuurlik heelwat verskille tussen die verskillende etnies-kulturele groeperinge binne hierdie streek bestaan het, kan daar tog sekere legitieme veralgemenings gemaak word. Die mense wat in die eerste eeu na Christus in die Mediterreense wêreld woonagtig was, het hulle menswees hoofsaaklik vanuit hulle verbondenheid aan andere verstaan (Joubert 1992:165). Daar was nie in die eerste plek sprake van individualiteit of individuele persoonlikhede nie, in die sin dat ' $n$ individu altyd as deel van ' $n$ groep beskou is en dat ' $n$ persoon se primêre identiteit onlosmaaklik verbonde was aan die groep waaraan die individu behoort het. Anders gestel, die groep waaraan jy behoort het, het bepaal wie jy is en hoe jy moet optree.

Die verwysing na God as Paulus se weldoener is aan die genoemde eerste-eeuse denkwêreld ontleen (Van der Watt 1996:36-38). Die antieke Bybelse omgewing het onder andere vanuit die sosiaal-maatskaplike weldoenerstelsel gefunksioneer. Volgens Avidov (2009:69) het die weldoenerstelsel gedui op ' $n$ interafhanklike verhouding tussen twee partye waarbinne erkenning aan die verskil in status en mag verleen is. Hierdie sisteem was in wese 'n persoonlike en vrywillige verhouding waarbinne die beginsels fides en officia gegeld het. Fides het beteken dat een van die partye onder die beskerming van 'n meerdere was. Officia het weer op die antieke waarde van die wederkerigheid gedui. Die verhouding tussen weldoener en kliënt was dus 'n sosiale stelsel wat binne die raamwerk van resiprositeit gefunksioneer het (Crook 2004:93).

Ons lees in Filippense dat Paulus enersyds, getrou aan die gebruik van sy tyd, sy dank teenoor God, en by name Jesus Christus, uitspreek. Ons sien egter ook dat hy wel breek met die algemene gebruik, naamlik dat hy hierdie beginsel nie op belangrike volks- of godsdienstige leiers van toepassing maak nie, maar wel op Jesus Christus. Binne die antieke Mediterreense wêreld het die Romeinse keiser die oppermag gehad. Hy was '... the all powerful patron in the Roman world' (Joubert 2000:26), maar in Jesus Christus plaas God die Christen binne 'n alternatiewe weldoener-kliënt-stelsel deur te verklaar dat God voortaan die 'beskermheer' van die gelowige as sy kliënt is (Pilch 2000:41). Jesus Christus funksioneer as die bemiddelaar tussen God as weldoener en die mense as God se kliënte (Fil 1:18-20). God as Paulus se weldoener is die bron, onderhouer en ook die inhoudgewer van sy alternatiewe waardestelsel. Die weldoener is die een wat sy kliënte uit sy oorvloed beskerm en versorg en hulle behandel asof hulle intieme familie is. Jesus Christus is 'n geskenk by uitnemendheid wat elke ander aardse weldoener oortref en wat deur God in die posisie van bemiddelaar 
geplaas is, maar wat ook bemagtig is om self as weldoener op te tree (Pilch 2004:12). Tog is daar ' $n$ baie duidelike hiërargie van waardes en ' $n$ ontologie van verhoudings te bespeur. God is en bly die primêre weldoener, Jesus die bemiddelaar en hoogstens die bemagtigende weldoener onder die heerskappy van God. Dit strook ook met ander tekste soos Johannes 5:19 wat ook duidelik maak dat alhoewel Jesus die bron van lewe is (Joh 1:4), Hy nogtans die vermoë daartoe van God as Vader ontvang het. Tog word die Jesus as bemiddelaar deur God by Paulus, net soos by Johannes, bemagtig om self as weldoener te kan funksioneer, sonder om daarmee God as die allerhoogste weldoener te misken.

\section{$\dot{\varepsilon} \mathbf{v}$ X $\rho เ \sigma \tau \tilde{\varphi}$}

Inleidend word daarop gewys dat die uitdrukking $\dot{\varepsilon} v$ X beteken dat ons een is met Christus Jesus. In en deur Christus as bemiddelaar het ons toegang tot die rykdom van God die Vader. Ons is een met Christus, deel van Hom, in Hom opgeneem en ons is deel van sy liggaam (Keck 2000:507). God handel in en deur Jesus met ons. Daarom kan Paulus ons ook elders beveel om die nuwe mens 'aan te trek' (Rom 13:14; Ef 4:24; Kol 3:10), wat eintlik beteken dat ons ons volkome met Jesus en die konsekwensies van die Jesus-gebeure moet vereenselwig nadat ons deur die doop en die geloof in Hom ingelyf is (Rom 6; Kol 2-3). Ons het nie meer 'n lewe van ons eie nie omdat ons deur die doop en die geloof saam met Christus gekruisig is en ons ou lewe daarmee beëindig is. Ons het toe saam met Hom opgestaan en só aan sy opstanding deel gekry. Hy is nou ons lewe (Kol 3:4) en dié lewe moet ons leef deur ons hoe langer hoe meer met Hom te vereenselwig en ons eie identiteit binne die dampkring van die fiktiewe familieverwantskap te vorm (Van der Watt 2006). Vervolgens word aandag geskenk aan die impak wat hierdie formulering van Paulus op die daarstel van 'n alternatiewe waardestelsel het (Gräbe 2006).

Ridderbos (1975:58) is van mening dat die verhouding tussen Christus en sy kudde so intiem is dat daar van sy volgelinge gesê kan word dat hulle 'in Christus' is (2 Kor 5:17). Daar bestaan egter talle standpunte oor presies wat die inhoud van hierdie formulering is. Die slotsom waartoe gekom word, is dat ons met hierdie formulering nie met ' $n$ mistieke eenwording deur sekere simboliese rituele te make het nie. Ridderbos (1975) stel dit soos volg:

an abiding reality determinative for the whole Christian life, to which appeal can be made at all times, in all sorts of connections, and with respect to the whole church without distinction. (bl. 59 [kyk na Kol 2:20; 3:1])

Ons het dus hier te make met die objektiewe heilsekerheid van Christus se kerk (Hawthorne 1996:163-169). Die formulering 'in Christus' plaas die Christengelowige binne 'n alternatiewe verwysingsraamwerk van waaruit gedink, gevoel en opgetree word. Dit is vir Paulus belangrik dat die Christengelowige haarself en dergelike lewensgebeure vanuit die historiese gegewe van die dood en opstanding van Jesus Christus sal herinterpreteer (Hawthorne 1996:163-169). Hierdie historiese feitlikheid maak dat die Christen na haarself as ' $n$ nuwe skepping in Christus kan verwys en dat sy nie meer na die 'vleeslike' geoordeel word nie (vgl. 2 Kor 5:15vv). Volgens Sang-Won (2001:30) verwys die formule 'in Christus' nie net daarna dat die individuele Christen by die heilsgebeure ingesluit word nie, maar dit het ook implikasies vir die onderlinge eenheid tussen Christene. $\mathrm{Al}$ is daar baie individuele Christene, vorm hulle almal saam die liggaam van Christus omdat hulle almal een is in Christus (Fuchs 2008:53; Gal 3:28).

Die bestaan 'in Christus' bepaal nie net vir die huidige die identiteit van die gelowige nie, maar het ook waarde vir die toekoms (Fee 1995:233). Ridderbos (1975:61) verwys in hierdie verband na Romeine 5:12ff. In hierdie gedeelte het Paulus dit oor die sekerheid van die Christengelowige se redding ten tyde van die parousia. Diesulkes wat in Christus is, sal saam met Christus ook die toekoms ingaan (Strecker \& Horn 2000:117). Hierdie formulering, asook Paulus se verwysing na die Filippense as 'hemelse burgers' (3:20), maak dit duidelik dat Paulus oorbeweeg van 'n eksterne lokus van kontrole na 'n transendente lokus van kontrole (vgl. Louw 2005). 'n Transendente lokus van kontrole handhaaf die verband tussen etiek, etos en identiteit. Toegepas op die situasie in Filippense, beteken dit die volgende: Selfs al is Paulus nou in die tronk of selfs al gaan dit baie sleg met hom, hy is ten alle tye ingemoeder in Christus. Niks kan hom skei van Christus nie. Sy denke, optrede en gevoelens word deur sy intieme verbintenis in en aan Christus bepaal. $\mathrm{Hy}$ is in Christus en nie in die wêreld nie. Hy het 'n nuwe status, 'n nuwe burgerskap en 'n nuwe weldoener. Sy lewe word nou deur'n alternatiewe waardestelsel bepaal. Hierdie alternatiewe waardestelsel word aangrypend bevestig in Paulus se verwysing na homself en Timoteus as diensknegte (slawe) en na die Filippense as heiliges. In die volgende gedeelte word hieraan aandag geskenk.

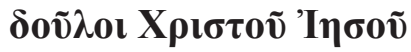

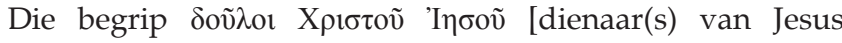
Christus] kan 'n identiteitsomskrywing aandui. Hierdie woorde impliseer dat Paulus homself ten volle en bewustelik aan Christus ondergeskik stel. Nie net dui dit op die vryspraak van Christus in sy lewe nie, maar ook op sy spesifieke amp (roeping) en die wyse waarop hy nie net sy identiteit verstaan nie, maar ook die konstruering van sy geprojekteerde self rig. Hy staan onder die gesag en opdrag

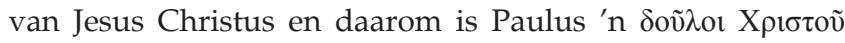

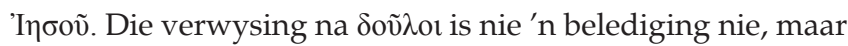
wel 'n hooggewaardeerde posisie in God se oë. Paulus keer dus hier die rangordes van die wêreld op sy kop. Hoe wend

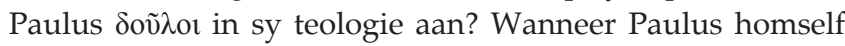
dus 'n slaaf van Christus noem, wil hy daarmee aantoon wat die verhouding tussen hom en Christus is. Soos 'n slaaf is hy in alles aan God en Christus onderworpe. Hy staan volkome in Christus se diens. God en Christus se wil het ook sy wil geword. Paulus verwys na homself en Timoteus as slawe en impliseer daardeur dat hulle in status ook gelyk voor God staan. Albei staan op dieselfde vlak - albei is net maar slawe van Christus. Hulle het dieselfde weldoener en staan in dieselfde diens. In die familie van Christus is almal dienaars van Christus. Malina en Pilch (2006:297) wys daarop dat 
slawe in die antieke tyd nie net dienaars was nie, maar totaal van hulle vryheid van keuse ontneem is. Hulle is ook gedwing tot 'enforced solidarity': 'To be slaves of Jesus Christ meant Paul and Timothy were for the utility of Jesus Christ, who controlled their choices and actions by solidarity - that is, by their commitment to Christ.' Nie net spreek Paulus sy eie status as slaaf van Christus aan nie, maar ook dié van die Filippense. Ook hul status en eer word nie meer deur hul aardse burgerskap bepaal nie, maar deur hulle status as

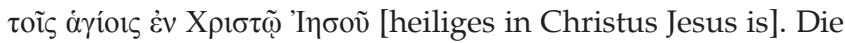
Filippense word as 'heiliges' aangespreek omdat die Heilige Gees van God in hulle woon. Hierdie inwoning van die Heilige Gees bied aan die Filippense die geleentheid om nuut te dink en nuut op te tree as mense wat tot die Koninkryk van God behoort. Die verlossing deur Christus en die inwoning van die Heilige Gees gee aan hulle 'n nuwe identiteit en status en daarom kan Paulus hulle oproep tot gedrag wat eie is aan hul nuwe identiteit. Die veronderstelling is dus dat daar binne die geloofsgemeenskap as fiktiewe verwantskap 'n onderliggende narratief geld waarvolgens die gelowiges hulle identiteit verstaan, hulle gedrag inrig, hulle toekoms projekteer en konflik hanteer. Hier word saam met Kok en Van Eck (2011:110) aanvaar dat die antieke mens nie dieselfde tipe toekomsverwagting gehuldig het as die moderne mens nie. Daar word met Malina (1996:182) saamgestem dat dit veral die hede, dan die verlede en dan eers die toekoms was wat vir die antieke mens belangrik was, anders as by ons waar die toekoms soms die hooffokus kry. Tog word 'n toekomsperspektief nie totaal van die antieke mens se denkraamwerk uitgesluit nie (vgl. Jer 29:11). Die feit dat die gelowiges geleef het in verwagting op die wederkoms, en die gevolglike oordeel wat sou kom, toon inderdaad aan dat die toekomsperspektief wel in ag geneem is en selfs gedrag beïnvloed het.

\section{ò $\pi 0 \lambda i ́ \tau \varepsilon v \mu \alpha$}

In 3:20 lees ons dat Paulus na die Filippense as ò $\pi \circ \lambda i ́ \tau \varepsilon v \mu \alpha$ verwys (Muddiman \& Barton 2010:1187). Die oorspronklike betekenis van die woord dui op 'n persoon se optrede as landsburger of sy of haar optrede in verhouding tot ander (Louw \& Nida 1989:508). Hier in Filippense 3:20 wil Paulus die Filippense daarop wys dat hulle tot ' $n$ heeltemal nuwe soort burgerskap behoort. Paulus maak dus in vers 27 op hul burgerlike bewussyn aanspraak. Wesenlik in hul denke was die feit dat Filippi 'n Romeinse kolonie was en dat die moontlikheid bestaan dat sommige van die Filippense selfs ook baie trots daarop was. Belangrik net om te onthou, is dat Paulus nie deur die gebruik van hierdie gedagte die Filippense tot burgery in die algemeen wil oproep nie, maar dat hy hulle van hul (alternatiewe) Christelike burgerskap en meegaande verantwoordelikheid bewus wil maak (Harrington 2009:137). Later, in Filippense 3:20, sal Paulus dit duidelik maak dat sy oproep tot uitnemende burgerskap daarop gemik is dat hulle aan 'n ryk behoort wat in alle opsigte die Romeinse Ryk in prestige en omvang oortref (Ascough 2003:149). Die punt wat Paulus wil tuisbring, is dat die primêre $\pi \circ \lambda i ́ \tau \varepsilon v \mu \alpha$ vir die Christene in Filippense nie

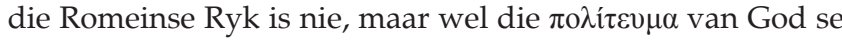
alternatiewe gemeenskap. Die Filippense leef vanuit 'n nuwe identiteit, hul identiteit in Christus (Gräbe 2006:293).

Die verwysing na $\pi$ o $\lambda i$ iqu $\mu \alpha$ word ook kortliks met die terme

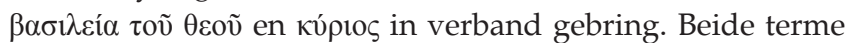
het implikasies vir Paulus en die Filippense se identiteit, etiek en etos. Gegewe die omvattendheid van die twee begrippe word slegs opmerkings gemaak wat die doel van die artikel

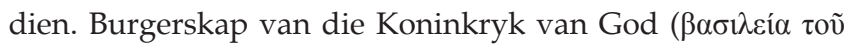
$\theta \varepsilon \circ \tilde{)})$ kan slegs deur geloof in Jesus Christus ontvang word (LaHaye \& Hindson 2006:281). Volgens Malina en Pilch (2006:374-375) funksioneer die begrippe 'Koninkryk van die hemel' en 'Koninkryk van God' as sinonieme vir mekaar. 'n Koninkryk is nie soos 'n moderne demokrasie nie met individualiteit en diversiteit nie, maar verwys eerder na ' $n$ groep mense wat onder die heerskappy van ' $n$ bepaalde koning staan. Die koning besit almal en alles in sy koninkryk en die onderdane is lojaliteit aan die koning as heer en meester verskuldig (Malina \& Pilch 2006:374). Paulus wys die Filippense daarop dat hulle in twee bedelings leef, die aardse en die hemelse (Elliot 2006:196; Muddiman \& Barton 2010:1186). Hulle is tegelykertyd in Christus maar ook in die realiteit van hulle dag - die antieke tyd. Binne die Pauliniese diskoers is daar ' $n$ duidelike hiërargie van waardes te bespeur. Die aardse dimensie is altyd ondergeskik aan die hemelse en daarom moet die Filippense altyd daarteen waak om nie in hul identiteit en etos aan die aardse bedeling gelykvormig te word nie (Blockmeuhl 2006:234). Paulus het egter met die verwagting geleef dat God spoedig die aardse bestel tot ' $n$ einde sou bring en sy hemelse ryk in volle mag sou vestig (vgl. Rom 8:18-25; 13:11-14; Elliot 2006:184). In die lig van sy oortuiging oor die verganklikheid van die aardse ryk is dit te verstane dat hy die Filippense aangespreek het om nie in hul toewyding te verslap nie. In sy bespreking van die 'hemelse burgerskap' wys Witherington III (1994:52) daarop dat Paulus nie die hemel slegs as die vaderland van die gelowige of as ' $n$ finale en ewige eindpunt beskou nie. $\mathrm{Hy}$ is van mening dat Paulus aan die hemel dink as die tuiste waar Christus tans is, tot en met die finale parousia (2 Kor 5:1-10). Verder is Witherington III van mening dat die hemel ' $n$ werklikheid is wat reeds in die persoon van Jesus Christus ' $n$ aanvang geneem het. In en deur Jesus Christus se aardse lewe is hierdie aardse wêreld reeds beïnvloed en deur God se Koninkryk verryk. Die werklikheid is dat die aardse wêreld van verbygaande aard is en dat die burgers van God se Koninkryk hulle eerder tot die waardes en realiteite van God se Koninkryk moet verbind. Hulle moet dit ook nou al sigbaar maak en nie passief tot die einde van die tyd wag nie (Dickson 2003:113; Ratzinger 2007:24).

Daar is ' $n$ interessante ontwikkelingsagtergrond tot die titel кúpıs. Malina en Pilch (2006:377) maak 'n onderskeiding tussen monoteïsme en henoteïsme. Eersgenoemde verwys na 'slegs-een-God-isme', terwyl henoteïsme na 'een-Godisme' verwys. Malina en Pilch (2006:377-378) is van mening dat Paulus nie monoteïsme nie maar henoteïsme voorgestaan het. Die implikasie is dat God een God tussen baie gode is 
en dat absolute lojaliteit aan Hom verwag word, maar dat die realiteit van ander gode nie ontken word nie (vgl. 1 Kor 8:5-6). Myns insiens is Barclay (2003:46) korrek as hy daarop wys dat kúpıs (1) na 'n eienaar of meester verwys, (2) later die amptelike titel van die Romeinse keiser sou word, (3) die aanspreekvorm vir die Romeinse en Griekse Gode was en (4) die benaming sou word waarmee die Hebreeuse YHWH in Grieks vertaal word (vgl. Gonzales 2008:xiii). Wanneer Paulus na Jesus as kúpros verwys, is Hy die ware Eienaar en Meester van die lewe, Koning van die Konings. $\mathrm{Hy}$ is waarlik God soos wat geen ander gode of afgode ooit kan wees nie en Hy is volwaardig God wat alleen aanbid moet word (Rhodes 2008:1186). Dit is vir Paulus belangrik dat die Filippense besef dat Christus as hulle kópıos die keiser as kúpıos in gesag, mag en status oortref. Dit is 'n feit wat sekere praktiese implikasies vir hul daaglikse lewe sou inhou. Die waardes van die Romeinse Ryk het in sterk kontras met die waardesisteem van die Hemelse Koninkryk gestaan. Filippense 2:5-11 is sekerlik een van die belangrikste tekste sover dit die Pauliniese verstaan van Jesus as die

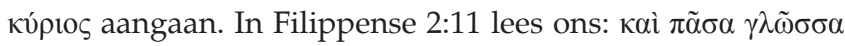

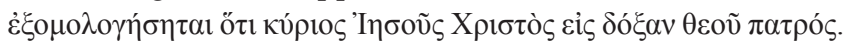

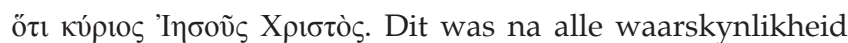
een van die eerste credo's van die Christelike Kerk (Barclay 2003:46). Die gedagte met hierdie woorde was dat die Filippense sal besef dat Christus 'n bemagtigde hoof is teenoor wie eer en lojaliteit bewys moet word. Ek stem op hierdie punt saam met Malina en Pilch (2006:378) dat ons moontlik hier met henoteïsme te doen het, in die sin dat absolute lojaliteit aan Jesus as Here verwag word, sonder om daarmee die absolute heerskappy van God as Vader te ontken. Paulus wil die Filippense se aandag daarop vestig dat hulle nie uit selfsug moet lewe nie, maar soos Christus, hul enigste кúpros, mekaar moet dien.

Die identiteit van die Filippense is in hul hemelse burgerskap

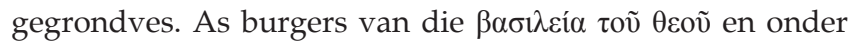
die eienaarskap van Jesus as die enigste en ware кúpı dit verreikende implikasies vir hul sosiaal-kulturele stelsel. Hierdie stelsel is gekenmerk deur lojaliteit binne die fiktiewe familiestruktuur. Dit het ook die weldoenerstelsel en die kategorieë eer en skaamte ingesluit. Paulus het nuwe inhoud aan die Filippense se verstaan van eer en skaamte verleen. Die mense wat in die eerste eeu na Christus in die Mediterreense wêreld woonagtig was, is deur hul soeke na openbare eer oorheers (Neyrey \& Stewart 2008:85). Hellerman (2005:165) maak die stelling dat persone soos Paulus, wat eer en skaamte as waardes wou konfronteer, blootgestel was aan openbare vervolging wat selfs tot die dood kon lei (vgl. 2 Kor 11:16-33). Hellerman (2005:165) is van mening dat dit Paulus se droom was dat die geloofsgemeenskap hulle eer sou verwerf deur hulle status en mag in diens aan mekaar op te offer. Dit het in radikale spanning gestaan met die mores van die Romeinse Ryk waar eer in die oë van mense die primêre dryfveer was. Die herinterpretasie van eer was veral in Filippi 'n grootse uitdaging, want antieke inskripsies bevestig dat daar uitsonderlike wedywering onder die elite in Filippi bestaan het (Hellerman 2005:88). Dit was ook die geval in Korinte, soos duidelik uit die vele epigrafiese en numismatiese materiaal blyk (vgl. Clarke 1993). Indien Paulus 'n gemeente sou beveel om op gegewe wyse op te tree en hulle doen dit, sou hulle aan hom eer betoon, en by implikasie ook aan die Vader en die Seun. Die slotsom waartoe Joubert kom, is dus dat, as 'n mens as 'n eervolle persoon erken word, dit ook behels dat die samelewing die waarde waarop hy of sy aanspraak gemaak het, erken. Dit is dus te verstane dat Paulus Christus en homself, tot die mate waartoe hy Christus se voorbeeld navolg, as tipos of voorbeeld voorhou. Die waarde waarop Paulus sy identiteit bou en wat sy etos rig, vind ons onder andere in Filippense 3:7-10, maar ook in Filippense 2:5-11 (Sumney 2007:8). Alles is waardeloos vergeleke met Christus. Wat Paulus doen, is om eer en skaamte as fundamentele kategorieë teologies en Christologies te herdefinieer. Wat in die Romeinse omgewing as 'n eer beskou word, is dalk iets om in Christus se waardestelsel voor skaam te wees, soos om die armes ter wille van persoonlike rykdom uit te buit, of om 'n oog vir 'n oog en tand vir 'n tand te verruil. Paulus daag die Filippense uit om nuut te dink en op te tree volgens hulle alternatiewe identiteit (hemelse burgerskap), etiek en etos soos vergestalt in hul weldoener, God, en die verhoogde bemiddelaar van God se guns, Jesus Christus. Jesus Christus het sy mag en status prysgegee om te dien en so die voorbeeld geword wat nagevolg moet word.

\section{Getransformeerde waardestelsel}

Filippense 2:6-11 word gelees teen die agtergrond van die

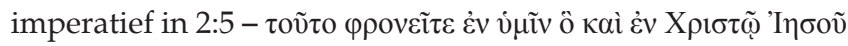

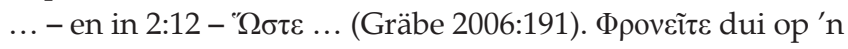
bepaalde gesindheid wat Paulus by die Filippense verwag. Die Filippense moet dieselfde gesindheid as Jesus Christus hê of hulle moet oor ander dink soos Christus oor diesulkes dink (Louw \& Nida 1989:325). Paulus kan hierdie opdrag gee omdat hy staatmaak op dit wat hulle reeds van Christus weet en wat hulle in Christus ervaar het en wat daarom ook deel is van hul lewe. Weereens is dit duidelik dat Paulus die verband trekna'n reeds bestaande simboliese universum en konsensus wat binne die alternatiewe familiestruktuur gefunksioneer het. Deur middel van die aanhaling van die bekende himne rig Paulus die denke van die geloofsgemeenskap om met die simboliese universum en die hiërargie van waardes wat in die fiktiewe familiekonteks geld, in ooreenstemming te kom. Die indikatief van Filippense 2:1 (Ë $\tau$ เs ỡ

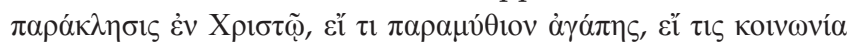

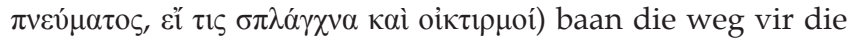
imperatief in Filippense 2:5. Die daaropvolgende gedeelte, Filippense 2:6-11, is die voorbeeld (imitatio Christi) waarop die Filippense hul dissipelskap skoei (Hawthorne 1996:169). Wat is die aard van hierdie voorbeeld van Christus?

Dit is dus die uitgangspunt van hierdie navorsing dat Paulus die Filippense se aandag op hul algeheel nuwe identiteit vestig en dat Filippense 2:6-11 die kern is van 'n Christelike etiek wat eie is aan God se kinders. Dit is 'n identiteit en etiek wat tot ' $n$ radikale etos van selfopofferende liefdesdiens en agting vir andere sal lei (Wolter 2006:209). Christenskap is dus nie maar net om in Jesus se voetspore te volg nie, 
maar is om vanuit 'n nuwe identiteit en etiek nuut te lewe (etos). Die voorafgaande bespreking oor die interpretatiewe moontlikhede word nou deur verdere eksegetiese merkers in Filippense 2:6-11 aangevul.

Christus se voorbeeld word in Filippense 2:5-11 aan die hand van die sogenaamde V-motief verduidelik (Kok 2012:14). Die V-motief illustreer dat Jesus die een is in wie God se werking in vier fases verloop het: sy voortydelike bestaan (2:6), sy menswording (2:7), sy vernedering en dood (2:8) en sy triomfantelike verhoging (2:9-11). Binne laasgenoemde konstruk word die verhoging-vernedering-verhoging van Jesus Christus op aangrypende wyse uitgebeeld (Reumann 2008:334-335).

Dit is reeds in Filippense 2:6 se inleidende woorde duidelik dat Jesus Christus se gesindheid geen vanselfsprekendheid was nie (ó $\varsigma \dot{\varepsilon} v \mu о \rho \varphi \tilde{n} \theta \varepsilon \circ \tilde{)})$. 'n Letterlike vertaling sou soos volg kon lui: 'in die vorm/gestalte van God'. Wanneer ons die presiese betekenis van ós $\dot{\varepsilon} v \mu о \rho \varphi \tilde{n} \theta \varepsilon \circ \tilde{v}$ wil verstaan, sal ons rekening moet hou met twee ander woorde wat met ó $\varsigma \dot{\varepsilon} v \mu о \rho \varphi \tilde{n} \theta \varepsilon \circ \tilde{v}$ oorvleuel, te wete $\dot{\varepsilon} v$ ó $\mu$ ot $\omega \dot{\mu} \mu \alpha \imath$ en

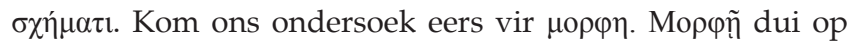
die aard en karakter van iets wat die uiterlike sowel as die innerlike insluit. Floor (1988:98) is van mening dat $\mu о \rho \varphi \tilde{n}$ op die uiterlike verskyningsvorm van iets dui, maar dan in so 'n mate dat dit nie in teenstelling met die innerlike aard staan nie. Dit is 'n uiterlike beskrywing, maar moet nie as 'n 'masker' beskou word nie. Dat Christus in die gestalte van God verskyn het, is ' $n$ aanduiding dat Hy in die volle wese van God gedeel het. Jesus Christus het in sy aard en wese oor Goddelike eienskappe beskik. Ware Goddelike mag en majesteit was wesenlik tot sy aard! Vervolgens meer oor $\dot{\varepsilon} v$ ó ot$\mu \alpha \tau \imath$ (2:7) wat soos volg vertaal word: 'om dieselfde te wees' of 'om in dieselfde toestand te wees' (Perchblacher 1990:293). Die derde woord in die trilogie wat Jesus se aard

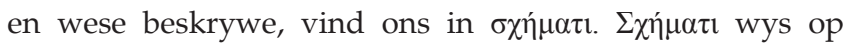
sintuiglike waarneming. Samevattend kan gesê word dat Paulus dit onomwonde aan sy lesers stel dat Jesus volkome mens en volkome God was! Hoe moes die Filippense die interaksie tussen hierdie twee gedagtes, dat Jesus volkome mens was maar tegelyk ook volkome God was, verstaan?

Die woord $\dot{\alpha} \rho \pi \alpha \gamma \mu \grave{v} v$ sal hiermee help. Die eerste betekenismoontlikheid is om iets onverwags met mag en krag van iemand weg te vat (gryp). Die nadere betekenis word omskryf as om iets wat jou toekom vanuit 'n magsposisie toe te eien (Martin 1967:135). Dit wil voorkom asof ons beide hierdie moontlikhede in Filippense 2:6 in gedagte moet hou. Die lesers sou dus kon aflei dat Jesus vanuit sy posisie die reg tot sy Goddelike mag gehad het, maar dat Hy dit nie gegryp het nie! Jesus het nie sy Goddelikheid tot sy eie voordeel geroof nie! (Floor 1988:99) Wat het Jesus dan gedoen?

In vers 7 lees ons dat hy nie krampagtig aan sy Goddelike majesteit en heerlikheid vasgehou het nie. Hy het Homself $\dot{\varepsilon} \kappa \varepsilon ́ v \omega \sigma \varepsilon v$. Bateman (2002:43) wys daarop dat dit in Paulus se tyd beteken het om jouself volledig tot die beskikking van iemand anders te stel. 'n Ander moontlike gedagtelyn is om alles wat jy het aan 'n arme weg te gee. Christus het Homself volledig weggegee! Jesus het Homself ontledig tot die status van 'n slaaf (Van der Watt 2006:v-ix). Wat is die punt? Jesus kon Homself in sy Goddelikheid laat geld het, maar het gekies om Homself in die mag van mense oor te gee. Nie net het Hy Homself in hul mag oorgegee nie, maar in sy alledaagse lewe was Hy aan die menslikheid van ons aardse bestaan onderworpe (Fowl 2005:254). Tot in die dood was Hy mens. Laasgenoemde oortuiging word afgelei uit

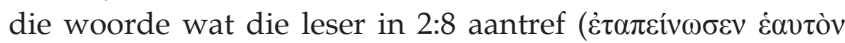

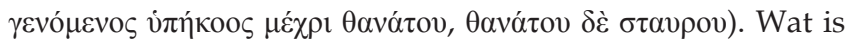
die implikasie van hierdie gedeelte vir die Filippense? Paulus wys die Filippense op die gesindheid wat by hulle móét wees en kán wees omdat hulle 'in Christus' is (Keck 2000:507). Laasgenoemde opmerking bring ons by die kwessie van identiteit, etiek en etos in Filippense.

Filippense 2:6-11 toon in gedagtegang ooreenskomste met die verhaal van Jesus se voete-was in Johannes 13 (Anderson, Just \& Thatcher 2009:255). Die verband tussen Johannes 13 (Jesus was die dissipels se voete) en Filippense 2:6-11 is vir die navorser ' $n$ aanduiding dat hierdie gedeeltes implikasies vir die Christelike identiteit, etiek en etos inhou. Die Christen vind in die voorbeeld van Christus haar of sy identiteit en internaliseer op grond van hierdie nuwe identiteit 'n alternatiewe etiek wat in 'n radikale etos van liefdesdiens gestalte vind (Gräbe 2006:290).

Die aanwending van die Christuslied is vir Paulus van die uiterste belang omdat die Filippense in die voorbeeld van Christus die wesenlike van dissipelskap ontdek (Gräbe 2006:291). Die belangrike is dat die Filippense nie net Christus as ' $n$ voorbeeld vind nie, maar dat die Christen in en deur Jesus Christus se heilsdaad (opstanding) in die persoon van Christus ingesluit word en in sy krag en lewe deel (Hawthorne 1996:163-169). Die Filippense lewe nou vanuit 'n nuwe identiteit, hulle is nou 'hemelse burgers' (Filippense 3:20). Paulus bevestig die nuwe identiteit van

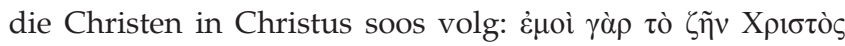

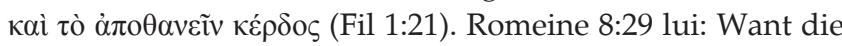
wat Hy vantevore verordineer om gelykvormig te wees aan die beeld van Sy Seun, sodat Hy die eersgeborene kan wees onder baie broeders. Net so sien ons soortgelyke gedagtes in 2 Korintiërs 3:18:

En terwyl ons almal met onbedekte gesig soos in 'n spieël die heerlikheid van die Here aanskou, word ons van gedaante verander na dieselfde beeld, van heerlikheid tot heerlikheid, as deur die Here wat die Gees is.

Hierdie teksgedeeltes bevestig dat die Christen 'n nuwe identiteit in Christus ontvang. Gräbe (2006:292) wys daarop dat Paulus se etiek in die volgende beelde, wat in 2 Korintiërs 5:17 en Galasiërs 6:15 voorkom, funksioneer: Nou is dit nie meer ek wat leef nie, maar Christus wat in my leef; verordineer om gelykvormig te wees aan die beeld van Sy Seun en 'n nuwe mens. Hierdie nuwe identiteit in Christus vra volkome gehoorsaamheid aan Hom. Paulus dring daarop aan dat Christene nie net sal naboots nie, maar daadwerklik hulle 
nuwe identiteit sal uitleef (Gräbe 2006:293). Dit is duidelik uit die voorafgaande dat die Christelike etos uit die nuwe identiteit in Christus ontspring. Dit is 'n radikale moraliteit vanuit ' $n$ alternatiewe identiteit. Laasgenoemde identiteit het ook Paulus se denke oor lyding beïnvloed.

In Filippense 1:29 konfronteer Paulus die denkraamwerk van die Filippense aangaande lyding. Lyding word in 1:28 en 1:29

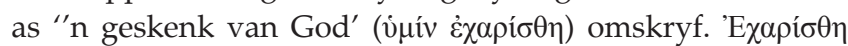
bevat die stam 'genade' (Kittel 1967:1078). Genade beteken 'n gratis en onverdiende gawe van God (Ef 4:32; Rom 8:32).

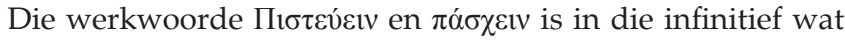
daarop dui dat die gawe van geloof in Christus en hul lyding vir Hom 'n voortdurende handeling is (Fowl 2005:60-67). Beide werkwoorde is kenmerkend van die lewe as ' $n$ burger in die Koninkryk van God (vgl. Fil 1:27).

Dit is duidelik dat Paulus lyding in direkte verband met Christus bring. Lyding vir die evangelie van Christus is nie 'n werklikheid buite om Christus nie, want as 'burgers van die hemel' is hulle wesenlik $\dot{\varepsilon} v$ X het, ly Paulus en sal die Filippense ook ly (Engberg-Pederson 2000:91).

\section{Etiese Indikatore ontsluit die Sinmotief \\ Dank en blymoedigheid}

Hawthorne (1983:6) maak dit duidelik dat die vreugde of blydskap waarna Paulus in Filippense verwys, op die oog af nie deur eksterne omstandighede uitgedoof kan word nie (Fil 1:18; 2:17), maar die interessante is dat sy blydskap tog deur eksterne omstandighede gevoed word. Die Filippense is vir Paulus ' $n$ bron van vreugde indien hulle vas bly staan in die Here (4:1) en positief op sy pleitrede vir eenheid reageer (2:2; Phillips 2002:20). Die vraag is nou hoe ons $\chi \alpha \rho \tilde{\alpha}$ moet verstaan? Dit dui op 'n kalm, rustige sekerheid wat nie deur die wêreldse onrustighede ontstel word nie omdat dit in geloof gegrondves is (Ware 2005:194). Geloof word dan as ' $n$ vaste vertroue in die lewende Here van die Kerk verstaan $(3: 1 ; 4: 4,10)$. Blydskap is vir Paulus nie soseer 'n gevoel of 'n emosie nie. Dit is 'n vaste oortuiging van sekerheid dat ek en my omstandighede in God vasgeanker is. Die blydskap wat Paulus ervaar, is sekerlik die resultaat van God in sy lewe, maar sy blydskap put ook energie uit sy besondere verhouding met die Filippense.

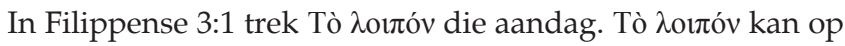
tweërlei wyse aangewend word. Dit sou gebruik kon word om 'n nuwe argument in te lei of om 'n sekere argument tot 'n gevolgtrekking te bring. Paulus stel 'n nuwe onderwerp aan die orde (Holloway 2001:15). Hy begin deur daarop te wys dat die Filippense blydskap in die Here moet vind.

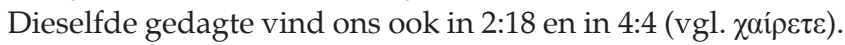

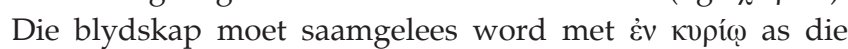
agent van die blydskap (mag die Here vir julle blydskap gee) of as die resultaat van 'n bepaalde toestand (wees bly vanweë julle verhouding met die Here). Met hierdie formulering

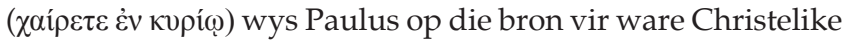
blydskap en die omgewing waarbinne blydskap gedy (Grindheim 2005:123). Die blydskap waarna die apostel verwys, is 'n ooglopende tema in die hele brief. In 4:10 is dit die enigste voorbeeld waar die apostel sy blydskap met 'n byvoeglike naamwoord belig (Floor 1988:177). Die vreugde wat hy belewe, is die resultaat van 'n intieme verhouding met die Here. Opvallend is dat hy nie sy omvangryke blydskap aan die geskenk van die Filippense koppel nie (4:18). Die geskenk van die Filippense was die sekondêre

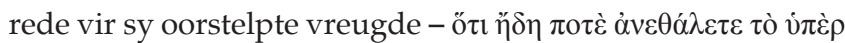

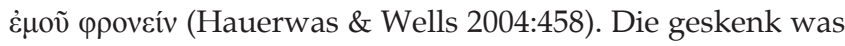
vir hom die sigbare daad van 'n onderliggende gesindheid wat aan die identiteit in navolging van Christus gekoppel kan word. Wat Paulus verder bly maak, is dat hy nooit uit

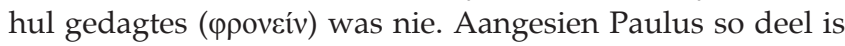
van hulle gedagtes, beleef hy baie vreugde, want dit beteken dat hulle geskenk sy welstand en dié van die evangelie wil bevorder. Gegewe die feit dat daar vir 'n tyd nie fisiese kontak tussen hulle was nie, het hulle gedagtevolle optrede hom weer met blydskap gevul, of soos Paulus dit gestel het

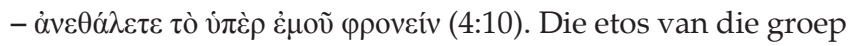
weerspieël dus dat hulle belange belyn is met die van die

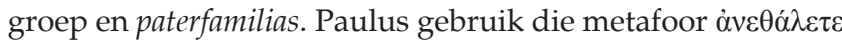
('om te blom, om te spruit') om aan sy blydskap kleur en geur te gee (Wiersbe 2008:146). Die Filippense se gesindheid het die lente in sy winter laat deurbreek!

\section{Lewe vergenoegd}

In 4:12 maak Paulus die bedoeling van sy skrywe baie duidelik

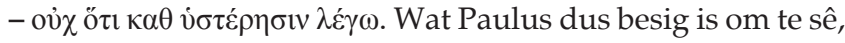
is dat hy nie skrywe met die gedagte om nog meer te vra of dat hy homself in 'n nog desperater hulpbehoewendheid bevind nie (Price 2008:65). Hy beskrywe sy ingesteldheid in sy situasie met 'n woord wat veral bekend was onder die

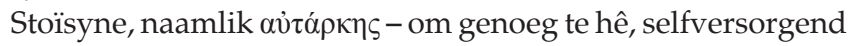
te wees, om vervuld te wees. Net soos die Stoïsynse filosowe het hy geleer om met sy omstandighede vergenoegd te wees (Perrotta 2001:67). Die omstandighede waarna hy verwys, word in 2 Korinthiërs 11:23-29 breedvoerig bespreek. Onder die Stoïsyne het $\alpha$ $\tau \dot{\alpha} \rho \kappa \eta \varsigma$ gedui op die ingesteldheid van die individu se denke en gesindheid waarvolgens die persoon totaal en al onafhanklik van enige ander persoon is. Dit is ' $n$ aangeleerde ingesteldheid wat nie afhanklik is van omstandighede en voorwaardes nie (Burer \& Miller 2008:378). Die belangrike verskil tussen die Stoïsyne en Paulus is dat Paulus se vergenoegdheid 'n gawe van God was en sterk in inter-relasionele terme beskryf word, anders as by die Stoïsyne (vgl. Fil 4:13; Engberg-Pedersen 2000:102). Paulus se intieme verhouding met Jesus Christus maak dat die gawe wat hy ontvang het, bloot 'n bonus is. Die Filippense skuld hom niks. In 4:12 stel Paulus hierdie gedagte van vergenoegdheid weer op die voorgrond.

In 4:12 verduidelik Paulus presies wat dit beteken as hy verklaar dat hy geleer het om vergenoegd te wees (Greidanus 2010:146). Twee keer lees ons oĩ $\delta \alpha$ wat dui op kennis wat berus op intuïsie of 'n absolute oortuiging. In 4:12 dui oĩ $\delta \alpha$ 
op die kennis wat hy deur ondervinding opgedoen het. Oĩ $\delta \alpha$ verbind $\tau \alpha \pi \varepsilon เ v o \tilde{\sigma} \theta \alpha \iota$ aan die voorafgaande gedeelte in vers

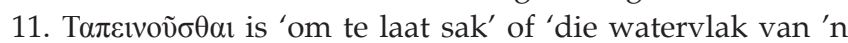
rivier wat daal'. In hierdie geval dui dit op die materiële en het dan veral op die basiese behoeftes vir die daaglikse lewe betrekking. Wat Paulus sê, is dat hy weet hoe dit voel om met

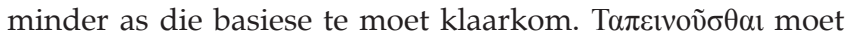
gelees word as ' $n$ antitese vir die daaropvolgende infinitief

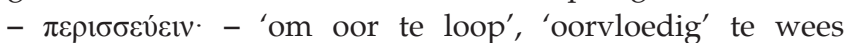
(Robertson \& Perschbacher 2003:115). Die infinitief wat op die voorafgaande antitese tussen skaarste en oorvloed volg, is interessant. Paulus maak in 4:12 van 'n verdere infinitief gebruik, naamlik $\mu \varepsilon \mu$ í $\mu \alpha 1$ - 'om geïnisieer te word', 'ingelyf te word', of 'om ingelei te word in die misterieuse kennis van 'n godsdiens of dogma'(Muddiman \& Barton 2010:201). Die perfektum wys daarop dat die proses afgehandel is en dat die effek blywend is. Wat Paulus sê, is dat hy deur sy omstandighede geleer het wat dit beteken om met oorvloed en skaarste te leef. Die bron van en moontlikheid vir hierdie gedrag is sy verhouding met God en die alternatiewe simboliese universum wat die Christusgebeure in die proses geskep het.

\section{Volhard in Apostoliese amp}

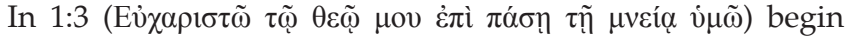
Paulus sy danksegging in die eerste persoon enkelvoud, 'n styl wat Hy regdeur die brief handhaaf (Harrington 2009:38).

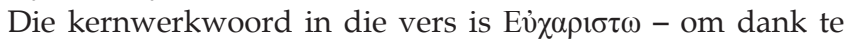
betoon (Danker 2000:462). Paulus betoon op 'n intieme persoonlike wyse aan God dank ( $\tau \tilde{\omega} \theta \varepsilon \tilde{\omega} \mu$ pov). Die gedagte dat Paulus voortdurend in sy gebede aan die Filippense dink en dat hy nie net aan hulle dink omdat hulle vir hom geld gestuur het nie, word verder uitgebou (Sumney 2007:7). Die rede vir hierdie standpunt vind ons daarin dat Paulus telkens in sy briewe die woord $\mu v \varepsilon i ́ \alpha$ gebruik (Rom 1:9; Ef 1:16; Filem 4). In elkeen van hierdie gedeeltes word $\mu v \varepsilon i ́ \alpha$ saam met 'danksegging' gebruik en dan spesifiek in die konteks van 'n gebed of 'om te onthou in gebed' (Ware 2005:166). Paulus dink ter wille van hulle belange en nie sy eie nie (vgl.

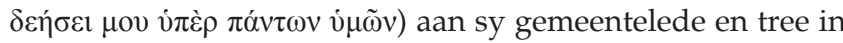
gebed vir hulle in.

Die woord $\delta \varepsilon \eta ́ \sigma \varepsilon 1$ - gebed - word twee maal in 1:4 aangetref (Danker 2000:143). Die woord wat meer algemeen vir gebed

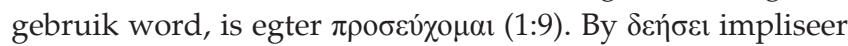
die oorspronklike betekenis "n tekort' óf "n behoefte'. As sodanig is dit 'n gebed wat tot God gerig word as die enigste Een wat die unieke behoefte kan vervul. Paulus se gebed is

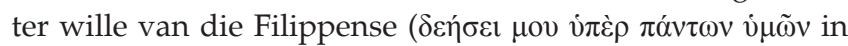
1:3), vir wie hy intens liefhet. Paulus ken hul behoeftes en die Filippense ken sy behoeftes. Daar bestaan dus wedersydse begrip vir mekaar en hul pleitredes tot God is 'n smeking dat God hierdie behoeftes sal vervul. Wanneer Paulus vir die Filippense bid, is dit met blydskap - $\mu \varepsilon \tau \grave{\alpha} \chi \alpha \rho \tilde{\alpha}$ (1:4). Laasgenoemde woorde kan vertaal word met 'ek is bly wanneer ek bid'. Nie net roep Paulus die Filippense op tot gebed nie, maar hy bied homself as 'n voorbeeld van die gesindheid waarmee daar vir mekaar en vir die geestelike belange van die ander gebid moet word. In hierdie sin word die gesindheid waarmee gebid word ook verskuif van die selfsugtige belange van die persoon wat bid en verplaas na die belange van ander en solidariteit met die groep (vgl. Horrell 2005:204-214).

Paulus waarsku die Filippense om nie die voorbeeld van die $\tau$ ov̀ אúvas na te volg nie, maar sy voorbeeld (Fil 3:17

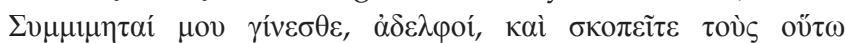

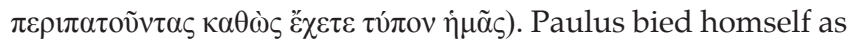
tipos binne die groter verband met Jesus Christus as sy tipos (Fil 2:5-11; Sandnes 2002:139). Paulus en die Filippense is deel van die nageslag van Abraham en daarvan is die Geestelike besnydenis ' $n$ bewys; daarom kan hulle vanuit hul nuwe identiteit uit genade leef (etiek en etos). In hierdie gedeelte bied Paulus sy eie lewe as ' $n$ inspirasie. Die Filippense moet voortdurend dit wat hulle by hom gesien, gehoor en geleer het, in dade omsit (Brower \& Johnson 2007:267).

In 4:8 gaan Paulus voort om die Filippense op die lewe in Christus te wys. Dit is 'n lewenswyse wat aan Paulus die krag en inspirasie bied om ten spyte van moeilike omstandighede te volhard. Die gedeelte begin met Tò $\lambda$ oı $\pi$ óv, wat nie dui op die einde van die brief nie, maar op die laaste van die imperatiewe wat die lesers presies wys hoe om 'sterk te

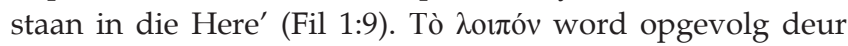
'n verwysing na sekere morele en etiese deugde (Hawthorne

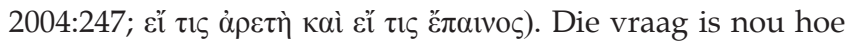
die Filippense daarin kan slaag om sterk te staan in die Here?

Paulus maak gebruik van twee begrippe om die Filippense

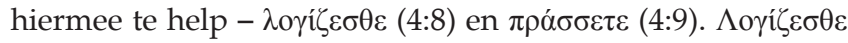
(4:8) dui op 'n oproep tot 'n onafhanklike morele besluit of om die waarde van hierdie genoemde sake met weldeurdagte beraad te bepaal (Mounce 1993:303). Die praesens imperatief dui op 'n handeling wat voortdurend uitgevoer moet word, met ander woorde 'n gewoontevormende handeling. Paulus vermeld 'n lys van agt kwaliteite wat die Filippense kan help om God se vrede as 'n werklikheid te beleef. Die eerste ses is byvoeglike naamwoorde in die meervoudsvorm en die laaste twee is naamwoorde in die enkelvoudsvorm. Louw en Nida (1989:133) wys daarop dat die eerste ses begin met die uitdrukking 'alles wat is', terwyl die laaste twee begin met 'watter deug daar ook mag wees'. Die oogmerk hiermee is om klem te plaas op die kern - 'bedink dit'. Paulus rig hierdie imperatiewe op grond daarvan dat die Filippense se identiteit in Christus ' $n$ indikatief is (Gräbe 2006:299). Gräbe is van mening dat, indien die Filippense hierdie reeks imperatiewe 'n praktiese deel van hul lewe maak, God se vrede oor hulle die wag sal hou. Die deugde waarna Paulus verwys, word ingelei deur die akkusatiewe relatiewe voornaamwoord $\ddot{\alpha}$ (Holmstrand 1997:122). Laasgenoemde maak die deur toe vir enige veralgemening en wil die Filippense se aandag vestig op die spesifieke sake wat hulle by hom geleer, gesien en gehoor het. Wat sal gebeur indien hulle hul kennis in

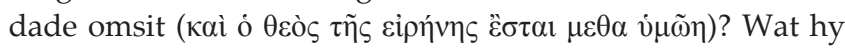
sê, is dat bekommernis, angstigheid en onsekerheid tot rus kan kom indien hulle hul gedagtes voortdurend rig op die lofwaardige deugde wat hy vermeld het. 


\section{Slotsom}

Binne die veld van die moderne stresmodel word na hanteringsmeganismes verwys as die mens se vermoë om by veranderende omstandighede aan te pas (Bergh \& Theron 2004:402). Bergh en Theron (2004:401) onderskei in die hanteringsmeganismes die volgende twee kategorieë naamlik (1) gedragsaanpassingsmeganismes (byvoorbeeld gebed, meditasie, oefening en kognitiewe strategieë) en (2) verdedigingsmeganismes (reaksies wat spontaan, outonoom en onbewustelik plaasvind).

Indien die reaksie van Paulus op die kategorieë stressors toegepas word, word die volgende waargeneem:

- Sowel Paulus as die Filippense het 'n situasie van verandering beleef waarbinne hulle moes aanpas. Paulus was in die tronk en die Filippense as jong en vormende geloofsgemeenskap was sonder die leiding van hulle leier.

- Aanpassingsgedrag: deur kognitiewe reoriëntasie help Paulus die Filippense om nuut oor hulself (identiteit 3:20), hulle rol en optrede in die Romeinse samelewing, hulle etiek en etos (2:15), die fokus op gebed (3:1-11) en die internalisering van vergenoegdheid (4:12) te dink. Paulus se eie lewe in navolging van Christus dien as voorbeeld van inspirasie (4:9) en die kontekstualisering van basiese Christelike beginsels $(2: 15 ; 3: 2-14 ; 4: 1-8)$.

- In die lig van bogenoemde was Paulus se verdedigingsmeganisme - met ander woorde sy natuurlike, outonome reaksie - geestelike volwassenheid soos vergestalt in die motief van blydskap, gegrond in 'n teologies-Christologiese selfverstaan (1:3; 3:1; 4:4, 10). Daarmee bedoel ons dat God as weldoener en Christus as bemiddelaar en bemagtigde weldoener en die fiktiewe familieverwantskap gebaseer op die inisiatief van God en die Christusgebeure (sterfte, opstanding, wederkoms, oordeel) sy identiteit en etos bepaal het.

Paulus het die Filippense bemagtig om hul identiteit en etos teologies te herdefinieer (Gupta 2010:164). Vanuit hierdie herdefiniëring ontspring 'n transformatiewe proses deurdat Paulus die gelowiges herinner aan die heiligheid wat van die kinders van God verwag word. Hierdie transformatiewe proses is ' $n$ deurlopende proses tot en met die koms van Christus. Daarom bid Paulus vir die Filippense dat hulle rein sal bly en vir niemand aanstoot sal gee tot op die dag

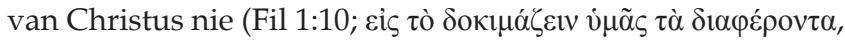

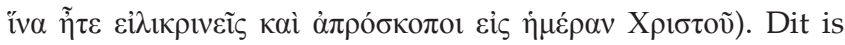
duidelik dat hierdie morele fokus nie net waarde het vir die Christelike etos nie, maar dat dit die Filippense help om hul unieke Christelike identiteit binne die Romeinse samelewing te behou (Gupta 2010:165). 'n Verdere belangrike moment is dat Paulus as tipos of voorbeeld binne 'n teologies-Christologiese konteks funksioneer. Paulus wys die Christene daarop dat hulle heilig is omdat hulle vanuit ' $n$ intieme verhouding met God lewe en daarom ook heilig moet optree (Gupta 2010:166). Blydskap te midde van uiters moeilike omstandighede is vir God se kinders 'n werklikheid. Paulus het blydskap ervaar omdat hy geleef het vanuit 'n herskepte identiteit en 'n herskepte waardestelsel,

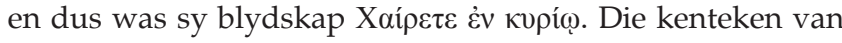
sy nuwe identiteit is die besnydenis van die hart deur die Heilige Gees. Paulus se herskepte waardestelsel was in Christus gevestig en het gerealiseer in 'n lewe van, onder andere, vergenoegdheid en gebed. Sy herstelde identiteit het dit vir hom moontlik gemaak om soos 'n blom oop te gaan en selfs soos ' $n$ hemelliggaam vir God te skitter. ' $n$ Verdere kenmerk van ' $n$ herskepte identiteit is dat hy in ' $n$ proses van transformasie is. Jesus Christus is voortdurend besig om hom deel te maak van sy lyding met die oog daarop dat hy al hoe meer aan die beeld van Christus gelykvormig word. Lyding is nie vir Paulus ' $n$ verleentheid nie, maar 'n geleentheid waarbinne God deur sy Gees en deur Jesus Christus transformerend met hom besig is. Lyding word binne ' $n$ teosentriese werklikheid herinterpreteer, want Paulus leef in Christus en deur Christus vanuit ' $n$ intieme verhouding met God. Hierdie transendente identiteit van Paulus maak dat hy met 'n herskepte identiteit, waardestelsel en konkrete etos leef. Laasgenoemde is in skrille kontras met die 'honde' wat die Joodse wettisisme op nuwe bekeerlinge wil afdwing (vgl. Gal 2:11-18; Dunn 2007:174). Paulus, gefundeer in Christus, is 'n waardige tipos van geestelike volwassenheid vir die Filippense en kan die Filippense op grond van hul herstelde identiteit oproep tot ' $n$ radikale etos wat op die basis van die imitatio Christi gebou word (Fil 2:5-10).

Paulus het daarin geslaag om ten spyte van die eksterne stressors (lydensmotief) met blydskap te kon leef (oorwinningsmotief). Paulus kon dit doen omdat hy vanuit 'n herstelde identiteit, etiek en etos geleef het. Die verband tussen die etiese indikatore ontsluit die potensiaal vir die moderne leser om ten spyte van eksterne stressors oorwinnend te leef. Die druk van eksterne stressors kan gerelativeer word, indien alternatiewe taal geskep kan word waarbinne die dekonstruktiewe ervaring daarvan nuwe sin en betekenis kan ontvang en ' $n$ hoopvolle toekomsperspektief in die proses geskep kan word. Daarvoor is inter alia fiktiewe verwantskapstrukture nodig, iets wat in die moderne tyd vol individualisme en 'selfagting'min in die kerk te sien is, maar steeds ' $n$ behoefte is. Mag die boodskap van Paulus en die stem van die geloofsgemeenskap deur die eeue weerklink in 'n oproep tot gemeenskappe wat bereid is om eensgesind vir mekaar om te gee in navolging van Christus wat homself gegee het, en mag dit hoop bring in ons tyd vol van oorvloedige stres, konflik en verandering.

\section{Erkenning Mededingende belange}

Die outeur verklaar dat hy geen finansiële of persoonlike verbintenis het met enige party wat hom nadelig kon beïnvloed in die skryf van hierdie artikel.

\section{Literatuurverwysings}

Achtemeier, P.J., Green, J.B. \& Thompson, M.M., 2001, Introducing the New Testament Its Literature and Theology, William B. Eerdmans, Grand Rapids.

Ascough, R.S., 2003, Paul's Macedonian Associations, Mohr Siebeck, Tübingen.

Anderson, P.N., Just, F. \& Thatcher, T., 2009, John, Jesus and History (Volume 2): Aspects of Historicity in the Fourth Gospel, Society of Biblical Literature, Atlanta. 
Avidov, A., 2009, Not Reckoned Among Nations: Text and Studies: Ancient Judaism 128, Mohr Siebeck, Tübingen.

Barclay, W., 2003, The Letters to the Philippians, Colossians and Thessalonians, Westminster John Knox Press, Louisville.

Bateman, I.V. (ed.), 2002, Authentic Worship: Learning Scripture's Voice, Applying its Truth, Kregal Publication, Grand Rapids.

Bergh, Z.C. \& Theron, A.L., 2004, Psychology in the Work Context, 2nd edn., Oxford University Press, Oxford.

Bockmuehl, M., 1997, A Commentary on the Epistle to the Philippians, A\&C Black, London.

Brower, E. \& Johnson, A. (eds.), 2007, Holiness and Ecclesiology in the New Testament, William B. Eerdmans, Grand Rapids.

Brown, T.G., 2003, Spirit in the Writings of John, T\&T Clark, London.

Brueggemann, W. \& Miller, P.D., 1995, The Psalms and the Life of Faith, Augsburg Fortress, Minneapolis.

Burer, M. \& Miller, J.E., 2008, A New Reader's Lexicon of the Greek New Testament Kregal Publications, Grand Rapids.

Clarke, A., 1993, Secular and Christian leadership in Corinth: A socio-historical and Exegetical study of 1 Corinthians 1-6, Leiden, Brill.

Crook, Z.A., 2004, Reconceptualising Conversion: Patronage, Loyalty and Conversion in the Religions of the Ancient Mediterranean, Walter de Gruyter, Berlin.

Danker, F.W. (ed.), 2000, A Greek-English Lexicon of the New Testament and other Early Christian Literature, The University of Chicago Press, Chicago.

Dickson, J.P., 2003, Mission-commitment in Ancient Judaism and in the Pauline Communities, Mohr Siebeck, Tübingen.

Dunn, J.D.G., 2007, The New Perspective on Paul, Wissenschaftliche Untersuchungen zum Neuen Testament (185), Mohr Siebeck, Tübingen.

Elliot, N., 2006, Liberating Paul: The Justice of God and the Politics of the Apostle, Fortress Press, Minneapolis.

Engberg-Pedersen, T., 2000, Paul and Stoics, T\&T Clark, Edinburgh.

Fee, G.D., 1995, Paul's letter to the Philippians, William B Eerdmans, Grand Rapids.

Floor, L., 1988, Perspektiewe op die Prediking van Paulus, NG Kerkboekhandel Transvaal, Pretoria.

Fowl, S.E., 2005, Philippians, William B. Eerdmans, Grand Rapids.

Fuchs, L.F., 2008, Koinonia and the Quest for an Ecumenical Ecclesiology: From Foundations through Dialogue to Symbolic Competence for Community, William B. Eerdmans, Grand Rapids.

Gonzales, G., 2008, Are You Curious about Kurios?, Xulonpress, Fairfax.

Gräbe, P.J., 2006, '... as citizins of heaven live in a matter worthy of the Gospel of Christ ...' in J.G. van der Watt (ed.), Identity, Ethics and Ethos in the NewTestament, pp. 289-302, De Gruyter, Berlin.

Greidanus, S., 2010, Preaching Christ from Ecclesiastes. Foundation for Expository Sermons, William B. Eerdmans, Grand Rapids.

Grindheim, S., 2005, The Crux of Election, Gulde-Druck, Tübingen.

Gupta, N.K., 2010, Worship that Makes Sense to Paul: A New Approach to the Theology and Ethics of Paul's Cultural Metaphors, De Gruyter, Berlin.

Harrington, D.J. (ed.), 2009, Philippians \& Philemon, Liturgical Press, Collegeville.

Harrison, J.R., 2003, Paul's Language of Grace in its Graeco-Roman Context, Mohr Siebeck, Tübingen.

Hauerwas, S. \& Wells, S. (ed.), 2004, The Blackwell Companion to Christian Ethics, Blackwell Publishing, Victoria

Hawthorne, G.F., 1983, Word Biblical Commentary (Volume 43) Philippians, Ward Books, Waco.

Hawthorne, G.F., 1996, 'The Imitation of Christ: Discipleship in Philippians', in R.N. Longendecker (ed.), Patterns of Discipleship in the New Testament, pp. 163-179, Longendecker (ed.), Patterns of Disciple
William B. Eerdmans, Grand Rapids.

Hellerman, J.H., 2005, Reconstructing Honor in Roman Philippi, Society for New Testament Studies, Monograph Series 132, Cambridge University Press, New York.

Holmstrand, J., 1997, Markers and Meaning in Paul. An Analysis of 1 Thessalonians, Philippians and Galatians, Coniectanea Biblica NewTestament Series 28, Almqvis \& Wiksell International, Stockholm.

Holloway, P.A., 2001, Consolation in Phillipians: Philosophical Sources and Rhetorical Strategy, Cambridge University Press, Cambridge, viewed 11 April 2012, from http://dx.doi.org/10.1017/CBO9780511487996

Horrell, D.G., 1999, Social Scientific Approaches to the New Testament Interpretation, T\&T Clark, Edinburgh.

Horrell, D.G., 2005, Solidarity and difference: A contemporary reading of Paul's ethics, T\&T Clark, London.

Jensen, J., 2006, Ethical Dimensions of the Prophets, Liturgical Press, Collegeville.

Joubert, S.J., 1992, 'Op maat van die musiek - die lewende familie van God in Filippi', Scriptura, S9a, 164-180.

Joubert, S.J., 2000, Paul as Benefactor. Wissenschaftliche Untersuchungen zum Neuen Testament 2. Reihe 24, Mohr Siebeck, Tübingen.

Joubert, S.J., 2009, Jesus 'n Radikale Sprong, Christelike Uitgewersmaatskappy, Vereeniging.
Keck, L.E. (ed.), 2000, The New Interpreter's Bible (Volume XI), Abington Press, Nashville.

Kittel, H. (ed.), 1967, Theological Dictionary of the New Testament, vol. 4, William B. Eerdmans, Grand Rapids.

Kok, J., 2010, 'Die rol van die etiek in die prediking: Nuwe navorsing in Nuwe Testamentiese etiek en die implikasie daarvan vir die prediking', Verbum et Ecclesia 31(1), Art. \#375, 10 pages, viewed 19 November 2011, from http://dx.doi. org/10.4102/ve.v31i1.375

Kok, J., 2011, 'Mission and ethics in Galatians', Hervormde Teologiese Studies 67(1), Art. \#896, 10 pages, viewed 11 April 2012, from http://dx.doi.org/10.4102/hts. v67i1.896

Kok, J. \& Van Eck, E. (reds), 2011, Unlocking the World of Jesus, Biblaridion, Pretoria.

Kok, J., 2012, 'Inleiding en teologie van Paulus I', ongepubliseerde lesingmateriaal, Departement Nuwe Testament, Universiteit van Pretoria.

LaHay, T. \& Hindson, E. (eds.), 2006, The Popular Bible Commentary, Harvest House Publishers, Eugene.

Louw, J. \& Nida, E. (eds.), 1989, Greek-English Lexicon of the New Testament based on Semantic Domains, Bible Society of South Africa, Cape Town.

Louw, D.J., 2005, Ratwerke van die Menslike Siel: Oor Volwassenheid en Lewensvaardighede, Sun Media, Stellenbosch.

Malina, B.J., 1996, The Social World of Jesus and the Gospels, Routledge, London.

Malina, B.J. \& Pilch, J.J., 2006, Social Science Commentary on the letters of Paul, Fortress Press, Minneapolis.

Malina, B.J. \& Neyrey, J.H., 1996, Portraits of Paul: An Archeaology of Ancient Personality, John Knox Press, Louisville.

Martin, R.P., 1967, Carmen Christi Philippians ii.5-11, Society for New Testament Studies, Monograph series 4, Cambridge University Press, Cambridge.

Meeks, W.A., 1993, The origins of Christian morality, Yale University Press, New Haven.

Mounce, W.D., 1993, The Analytical Lexicon to the Greek New Testament, Zondervan Publishing House, Grand Rapids.

Muddiman, J. \& Barton, J., 2010, The Pauline Epistles, Oxford University Press, Oxford.

Neyrey, J.H. \& Stewart, E.C. (eds.), 2008, The Social World of the New Testament: Insight and Models, Hendrickson Publishing, Peabody.

Perrotta, K., 2001, Philippians: A Letter to Friends, Loyola Press, Chicago.

Perschbacher, W.J. (ed.), 1990, The New Analytical Greek Lexicon, Hendrickson Publishers, Peabody.

Phillips, J., 2002, Exploring Ephesians \& Philippians: Expository Commentary, Kregal Publications, Grand Rapids.

Pilch, J.J., 2000, Healing in the New Testament: Insights from Medical and Mediterranean Antroplogy, Fortress Press, Minneapolis.

Pilch, J.J., 2004, The Cultural World of the Prophets: The First Reading and Responsorial Psalm (Year A), Liturgical Press, Collegeville.

Porter, S.E. (ed.), 2005, Pauline Studies (Volume 2): Paul and his Opponents, Brill, Leiden.

Porter, S.J. (ed.), 2008, Pauline Studies (Volume 5): Jew, Greek and Roman, Brill, Leiden.

Price, R., 2008, Successful Christianity: What is it?, AuthorHouse, Bloomington.

Ratzinger, J., 2007, Eschatology: Death and Eternal Life, 2nd edn., Catholic University of America, Washington, D.C.

Reumann, J., 2008, Philippians: A New Translation with Introduction and Commentarary: Philippians, vol. 33B, Yale University Press, New Haven.

Rhodes, R., 2008, Angels Among Us: Seperating Fact From Fiction, Zondervan, Minneapolis.

Ridderbos, H., 1975, Paul: An Outline of his Theology, William B. Eerdmans, Grand Rapids.

Robertson, A.T. \& Perschbacher, W.J., 2003, Word Pictures of the New Testament (Volume One), Kregal Publications, Grand Rapids.

Sandnes, K.O., 2002, Belly and Body in the Pauline Epistles, Society for New Testament Studies. Monograph Series 120, Cambridge University Press, Cambridge.

Sang-Won, S.A., 2001, Corporate Elements in Pauline Anthropolgy: A Study of Selected Terms, Idioms and Concepts in the light of Paul's Usage and Background, Analecta Biblica 148, Editrice Pontificio Instituto Biblico, Roma.

Strecker, G. \& Horn, F.W., 2000, Theology of the New Testament, Berlin, De Gruyter.

Sumney, J.I., 2007, Philippians: A Greek Student's Intermediate Reader, Hendrickson Publishers, Peabody.

Van der Watt, J.G. (ed.), 2006, Identity, Ethics, and Ethos in the New Testament, Walter de Gruyter, Berlin.

Ware, J., 2005, The Mission of the Church in Paul's letter to the Philippians in the Context of Ancient Judaism, Brill, Leiden.

Wiersbe, W.W., 2008, Joyful Even When Things Go Wrong: New Testament Commentary, Philippians, David C. Cook, Colorado Springs.

Witherington III, B., 1994, Paul's Narrative Thought World: The Tapestry of Tragedy and Triumph, Augsburg Fortress, Minneapolis.

Wolter, M., 2006, 'Pauline ethics according to 1 Corinthians', in G. van der Watt (ed.), Identity, Ethics and Ethos in the New Testament, pp. 199-217, De Gruyter, Berlin. 